\title{
UM "ÓRGÃO DOS AGRICULTORES BRASILEIROS": Algumas propostas da Moderna Agricultura na Revista Agrícola paulista (1895-1907)
}

\author{
A "ORGAN OF BRAZILIAN FARMERS": \\ Some proposals of the Modern Agriculture in Revista Agrícola São Paulo (1895-1907)
}

Amilson Barbosa Henriques*

\begin{abstract}
RESUMO: Este artigo se insere dentro da bibliografia especializada sobre a agricultura no Brasil, especialmente no Estado de São Paulo. O seu objetivo é ressaltar as propostas de modernização da agricultura em São Paulo no final do século XIX e início do século XX, em contraposição, ou substituição aos métodos e técnicas agrícolas considerados tradicionais e efetuados historicamente na agricultura brasileira. As propostas de modernização agrícola publicadas na Revista Agrícola giravam em torno de diferentes assuntos, como: diversificação agrícola, adubação química e natural, cultura intensiva, mão-de-obra, povoamento e colonização, núcleos coloniais dentro dos moldes da moderna agricultura então desejada, instrução agrícola por meio de campos de experiências e demonstração, ensino agrícola, a mecanização, o que era chamado na época de Moderna Agricultura, em substituição ao que era considerado como agricultura rotineira ou atrasada, praticada deste o início da agricultura no Brasil.
\end{abstract}

PALAVRAS-CHAVE: Moderna Agricultura; Estado de São Paulo; cafeicultura; Revista Agrícola.

ABSTRACT: This article inserts itself into the historical analyses upon agriculture in Brazil, especially in the State of São Paulo. Your goal is to stand out the agricultural modification proposals in São Paulo in the final century XIX and early century XX, in opposition or substitution for the agricultural methods and techniques considered to be traditional, and historically effectuated in Brazilian agriculture. The agricultural modification proposals published in the Revista Agricola turned around different subjects, such as: agriculture diversification, natural or chemical manuring, intensive culture, labor, population and colonization, colonial areas attending the desired patterns of modern agriculture by then, agricultural instruction through experience and demonstration fields, agricultural education, mechanization, which was called Modern Agriculture by that time, in substitution for what was considered to be routine and outdated agriculture, practiced since the beginning of agriculture in Brazil

KEYWORDS: Modern Agriculture; State of São Paulo; coffee growing; Revista Agrícola.

\section{Introdução}

Este artigo consiste na exposição parcial dos resultados de nossa dissertação de mestrado, bem como das pesquisas em curso no doutoramento. 0 artigo aborda as propostas de modernização da agricultura contidas na Revista Agrícola ${ }^{1}$ uma das primeiras publicações especializadas em agricultura no Estado de São Paulo.

\footnotetext{
* Mestre em História. Doutorando em História pelo Programa de Pós-Graduação do Departamento de História da Faculdade de Ciências e Letras - Unesp - Assis. E-mail: amilsonbarbosa@zipmail.com.br.

${ }_{1}$ Revista Agrícola. Órgão da Sociedade Pastoril e Agrícola. São Paulo, 1895. Este periódico possuía publicação mensal, circulando em vários Estados brasileiros, mas principalmente em São Paulo, onde possuía sua maior acolhida em assinaturas. A revista seguiu publicação entre os anos de 1895 a 1907 somando 149 números com uma média de 35 a 50 páginas cada edição, sendo substituída pela revista Fazendeiro, revista mensal de agricultura, indústria, comércio, dedicada especialmente aos interesses da lavoura cafeeira. São Paulo: Tip. Brazil Rothchild \& Cia, em 1908. A Revista Agrícola passou por diversas reformulações estruturais durante o curso dos anos, modificando-se também em relação a seus proprietários, sendo que no período de 1895 a 1896 seu proprietário era a Sociedade Pastoril e Agrícola tendo como diretor o fazendeiro José Leite da Costa Sobrinho, e redatores Carlos Botelho, Luiz Pereira Barreto e J. N. Domingos Jaguaribe. De 1901 a 1907 seu diretor foi Fernando Werneck, fazendeiro em São Paulo, tendo como redatores, Carlos Botelho, Luiz Pereira Barreto e Santos Werneck, todos fazendeiros em São Paulo. Neste período o periódico era de propriedade da Sociedade Paulista de Agricultura, Comércio e Indústria. A referência no título do presente artigo era uma expressão usada na Revista.
} 
Embora a pesquisa procure analisar uma ampla gama de manuais agrícolas, bem como centenas de artigos no periódico citado, no momento a preocupação será concentrada na leitura de alguns artigos ${ }^{2}$. O periódico analisado está profundamente relacionado com a sociedade na qual foi gerada, a grande produção cafeeira, a incipiente mão de obra assalariada e livre, bem como 0 contexto de superprodução da rubiácea e a crise econômica advinda em conseqüência. Desta feita, a leitura deste periódico permite, ao mesmo tempo, proceder a uma descrição deste meio social, que emerge das entrelinhas dos textos, e ressaltar as críticas e concepções dos autores a respeito dela, além é claro, das proposições para a mudança da agricultura praticada.

O objetivo deste trabalho é situar o momento histórico e acentuar algumas propostas de modernização da agricultura através de alguns autores e que foram discutidas, ensaiadas, experimentadas e analisadas por dezenas de agrônomos, fazendeiros e políticos no final do século XIX e adentrando o século XX em São Paulo, sendo relatadas principalmente através da Revista Agrícola já citada. Estes artigos (textos) são analisados pelo ponto de vista de uma história política e da ciência, ou seja, procura-se penetrar nas relações sociais que ele pressupõe e as relações que ele mantém com a realidade histórica em que foi produzido e para a qual foi dirigido. Além disso, existe a preocupação com a história ambiental, a relação dos fazendeiros e agricultores para com 0 meio ambiente e do meio ambiente interagindo com o homem³.

\section{Agricultura e ciência no Brasil}

Como destacou Nicolau Sevcenko, a expansão dos povos europeus pelo planeta com as navegações, a partir do século XVI, marcou o início de uma intensa troca de plantas, animais e tecnologias para todos os cantos. Animais, plantas, doenças, microorganismos, técnicas e conhecimento viajaram por todo o mundo em velocidade cada vez maior, causando diversos impactos ecológicos e sociais numa dimensão nunca antes realizada.

A partir do século XVIII as práticas agrícolas e a tecnologia entraram definitivamente para 0 domínio da ciência. Ansiosos em dominar e conhecer metodicamente a natureza, com critérios científicos, centenas de naturalistas percorreram o mundo classificando a natureza, descrevendo, estudando e mapeando o planeta. Ao mesmo tempo, comerciantes e colonizadores levavam e traziam plantas, animais e técnicas de cultivo de um canto para o outro do mundo. Para Sevcenko, se for observado o processo da expansão européia sob a condição de expansão colonial, as pessoas podem interpretá-la como uma disputa declarada contra a natureza. "A expansão européia

\footnotetext{
2 HENRIQUES, Amilson Barbosa. A cultura rotineira e a lavoura racional: proposições na Revista Agrícola (São Paulo, 1895-1907). Dissertação (Mestrado em História) - Faculdade de Ciências e Letras - UNESP/Assis. 2010.

3 WORSTER, Donald. "Transformações da Terra: para uma perspectiva agroecológica na história." Ambiente \& Sociedade, Campinas, v. V, n. 2, ago./dez. 2002; v. VI, n. 1, jan.jjul. 2003.
} 
se fez em função da exploração de recursos naturais" (minérios, metais preciosos ou vegetais), em especial por conta da peculiaridade do hemisfério sul, zona tropical por excelência, "ter características de insolação que dão aos seus vegetais em geral condição de desenvolver substâncias estimulantes"4.

Durante o século XVIII e XIX, as ciências de um modo geral entraram nos estudos agrícolas 5 . Alguns exemplos do "avanço" da ciência sobre a agricultura na Europa no século XVIII e XIX podem ser resumidamente destacados: No Reino Unido (Inglaterra), Arthur Young entre 1763 e 1767, parece ter feito mais de 2.000 experiências em todos os domínios da agricultura. $\mathrm{Na}$ Alemanha, Justus Liebig estudou a composição química do solo ajudando a detectar mais tarde as suas necessidades de compostos para a agricultura. Na França, houve um forte movimento agronômico que culminou na segunda metade do século XVIII com Sociedades de Agricultura, concursos teóricos, práticos e experimentos ${ }^{6}$. Bem como, nos Estados Unidos, as primeiras inovações nas práticas agrícolas surgiram no início do século XIX. Neste país surgiu também uma espécie de "movimento conservacionista" no final do século XIX, com o apoio do governo, através de seu departamento de agricultura7.

Sendo assim, a agricultura desejada durante boa parte do século XIX, deveria ser pautada pelo conhecimento científico, ser norteada por ela, assim como outros aspectos da sociedade: "Sob o domínio da idade da razão, a agricultura não poderia mais ser praticada por métodos transmitidos de geração a geração pela rotina e pelos costumes, sem submeter-se a métodos racionais e controlados."8

Também no Brasil a ciência moderna tocou seu solo. Segundo Heloisa Domingues, as primeiras iniciativas neste sentido surgiram quando D. João VI se transferiu para o Rio de Janeiro em 1808, e trouxe a partir deste fato, dezenas de botânicos e naturalistas com o objetivo de fundar jardins botânicos, cujas funções, na época, incluíam pesquisas e difusão de conhecimentos e experiências sobre a fauna e a flora da colônia. Ao mesmo tempo, algumas escolas passaram a ministrar cursos agrícolas que foram criados para difusão de novos conhecimentos sobre as

\footnotetext{
${ }^{4}$ SEVCENKO, Nicolau. "O Front Brasileiro na Guerra Verde: vegetais, colonialismo e cultura." Revista USP. n. 30, 1996, pp. 108-119. p. 110.

5 DOMINGUES, Heloisa Maria Bertol. Ciência: um Caso de Política. As relações entre Ciências Naturais e a Agricultura no Brasil-Império. Tese (Doutorado em História). São Paulo: FFLCH-USP, 1995.

${ }^{6}$ ABRAMOVAY, Ricardo. Paradigmas do capitalismo agrário em questão. São Paulo, Edusp, 2007.

7 TRIMBLE, Stanley. "Perspectives on the History of soil erosion control in the Eastern United States." In: Agricultural History Review. N. 59, 1985.

${ }^{8}$ ZARTH, Paulo Afonso. "Tecnologia e agricultura: das práticas rotineiras aos exemplos dos povos cultos." Primeiras Jornadas de História Regional Comparada. Porto Alegre, 2000, p. 1.
} 
práticas agrícolas. Estes podem ser considerados os primeiros esforços para dar início à pesquisa científica nesse campo. ${ }^{9}$

Contudo, apenas no final do século, em 1887, é que a pesquisa científica e sistemática sobre a agricultura teve início efetivo no Brasil. Sobre isso, alguns autores destacam que tais práticas de pesquisa científica e sistemática sobre agricultura no país apenas teve início com a instalação da Imperial Estação Agronômica de Campinas, sob a direção do austríaco, Franz Wilhelm Dafert que foi contratado pelo governo brasileiro para instalar este instituto de pesquisa agronômica, seguindo o modelo alemão para o desenvolvimento da agricultura. ${ }^{10}$

Neste momento, como se sabe, o café era o principal produto de exportação do país. Até por isso, segundo Reginaldo Meloni, o local escolhido para implantação do Instituto fora Campinas, na maior região produtora de café do interior do Estado de São Paulo. Ao que parece, até então, as vantagens oferecidas pela abundância de terras virgens não havia estimulado a pesquisa e 0 aumento da produtividade, mas o esgotamento do solo e os problemas com mão de obra levaram 0 governo a adotar uma política de investigação e pesquisas sobre os problemas da agricultura brasileira.

Segundo Meloni, Dafert não teve a simpatia dos plantadores de café. Ele atribuiu as dificuldades de introdução de novas tecnologias a dois aspectos: de um lado, a produção em forma tradicional, "rotineira", que obedecia a uma racionalidade econômica típica na história do Brasil, na medida em que aproveitava a fertilidade natural do solo ia incorporando novas áreas virgens a cada ciclo de esgotamento do solo e dos arbustos em conseqüência produtiva, como chamou Stanley Stein de "a expansão irresistível do café".11 De outro lado, as práticas de plantio obedeciam a critérios diferentes dos exigidos pela racionalidade técnica dos cientistas e estudiosos no assunto e, por isso, o costume de plantar os cafeeiros em linha reta, propiciando a erosão do solo, era uma forma de melhor observar e controlar os escravos. Os escravos, dizia Dafert, "eram inimigos declarados das linhas ordenadas". Além disso, os cafeicultores viam nessa simetria um sinal de disciplina e método. ${ }^{12}$

Apesar disso, tanto no Brasil como na Europa e nos Estados Unidos, os agricultores mantinham práticas milenares de cultivo e ofereciam resistências às inovações na agricultura. Os "propagandistas" de novas tecnologias atribuíam essas dificuldades ao tradicionalismo dos

\footnotetext{
9 DOMINGUES, Heloisa M. Bertol. "As Ciências Naturais e a Construção da Nação Brasileira." Revista de História. N. 135, 2. sem. 1996, 41-60.

${ }^{10}$ MELONI, Reginaldo Alberto. Ciência e Produção Agrícola: A Imperial Estação Agronômica de Campinas 1887-1897. São Paulo: Humanitas, 2004.

11 STEIN, Stanley J. Grandeza e Decadência do Café. São Paulo: Brasiliense, 1961, p. 14.

12 DEAN WARREAN. "The Green Wave of Coffee: Beginnings of Tropical Agricultural Research in Brazil." In: Hispanic American Historical Review. Duque University Press, Vol. 69, n. 1. 1989. P. $97-98$.
} 
camponeses. Slicher van Bath demonstrou que os adeptos da "nova agricultura" na Europa "consideravam-se a si próprios demasiados importantes como portadores da luz nas trevas da ignorância e do atraso para poderem ver a situação tal como ela era na realidade". Com esta forma de pensar, eles eram tão obcecados pelas novidades que desconsideravam tudo o que era antigo. ${ }^{13}$

\section{Agricultura moderna e agricultura tradicional}

Podem ser resumidamente destacadas algumas das características da moderna agricultura que estamos analisando em São Paulo, quais sejam: o uso de princípios e pesquisas científicas e tecnologias na organização do trabalho agrícola, a diversificação da agricultura (policultura), a implantação de colônias para fixar o colono a terra servindo estes como trabalhadores eventuais na grande lavoura de exportação, produzindo ainda alimentos ao mercado interno e externo, tornandoos pequenos proprietários, a pesquisa agrícola para a produção ou adaptação de novos conhecimentos, o ensino agrícola, bem como a intensificação agrícola no cultivo do solo, o uso de defensivos e adubos (químicos e orgânicos) em conjunto com a mecanização da lavoura, o advento de campos de experiências e demonstração de culturas onde os agricultores poderiam ser instruídos e vislumbrar as práticas e instrumentos agrícolas modernos em ação, bem como, a divulgação de diferentes culturas agrícolas e os seus resultados, para que servisse de modelo a ser imitado, vislumbrando-se a possibilidade da implantação da policultura para abastecimento do mercado interno e externo, entre outras características.

Deste ponto, a prática da moderna agricultura seria a contraposição do que era observado no Brasil em matéria agrícola: a chamada Agricultura Tradicional ou agricultura de coivara14, praticada desde os tempos coloniais, de técnicas e instrumentos simples (a foice, o machado, a enxada e o tição eram os seus símbolos principais), baseava-se na derrubada e queimada de florestas virgens e de solos férteis, a fim de abrirem-se novos campos de cultivo, o plantio era desordenado e o solo era utilizado sem nenhuma forma de correção e adubação. Esse modelo de exploração do solo induzia a uma espécie de "nomadismo agrícola", pois o campo aberto pela queimada, a princípio muito fértil, desgastava-se rapidamente por outras queimadas e pela falta de cuidados em cerca de 20 a 30 anos a terra era inutilizada para a agricultura. Seguia-se então uma

\footnotetext{
${ }^{13}$ SLICHER VAN BATH, Bernard. História Agrária da Europa Ocidental (500-1850). Lisboa: Presença, 1976.

14 Os nomes ou conceitos variam dentro da historiografia, ver, por exemplo: SCHMIDT, Carlos Borges. Técnicas Agrícolas Tradicionais e Primitivas. São Paulo: Conselho Federal de Cultura e Departamento de Assuntos Culturais, 1976.
} 
nova derrubada e queimada de matas para a exploração agrícola expandindo a área cultivada, deixando para trás campos desgastados. ${ }^{15}$

Analisando através de alguns autores os motivos da aderência ou não dos agricultores às práticas mais modernas de lida com o solo, Jon Elster falou sobre as alternativas apresentadas pela bibliografia para explicar o conflito entre inovação e tradição e que consistiram, para 0 autor, em compreender três argumentos básicos, pela ordem: a motivação, a tradição e as diferenças de oportunidades. Por exemplo: Elster destacou os estudos de Genovese, nos Estados Unidos, para quem a falta de investimentos em tecnologia pelos escravistas daquele país era uma questão de motivação: preferiam ostentar a investir. Outro exemplo dado é de North e Thomas os quais, tratando dos senhores feudais europeus, concluíram que era a falta de oportunidades de investimentos o fator decisivo para a ausência de atenções em novas tecnologias.

Outros autores, segundo Elster, argumentaram que a "resistência a mudanças técnicas nas sociedades campesinas do passado e do presente deve explicar-se pela inércia, o conservadorismo ou tradicionalismo do campesinato."16 Contudo, Elster considerou como equivocadas as interpretações com base nas motivações e no tradicionalismo e preferiu optar metodologicamente pela alternativa das diferenças de oportunidades.

Segundo Paulo Zarth, Henri Mendras concluiu que o camponês, embora tradicional e vivendo sob a égide da rotina, do costume e da tradição, não rejeita a inovação, mas as incorpora com precaução: "no final das contas, é essa subordinação da escolha das inovações em relação à rotina, que faz com que as sociedades camponesas sejam tradicionais, sem que, por isso recusem as mudanças". 17

Slicher van Bath, por sua vez, fez conclusões parecidas em seu livro sobre a agricultura européia. Referindo-se à agricultura na época moderna, afirmou que:

[...] existe uma grande distância entre a nova agricultura dos adeptos da nova escola e a maneira como os camponeses continuavam a praticar a agricultura. Estes - e muitas vezes não sem alguma razão - apegavam-se aos processos que tanto eles mesmos como os seus antepassados desde sempre tinham aplicado. Em geral, só meia dúzia de latifundiários é que se atreviam a fazer experiências, enquanto os camponeses observavam as operações com olho incrédulo e reprovador. ${ }^{18}$

\footnotetext{
15 DEAN, Warrean. A Ferro e Fogo: A História e a Devastação da Mata Atlântica Brasileira. São Paulo: Cia. das Letras, 1996.

${ }^{16}$ ELSTER, Jon. "La Motivación de los agentes económicos en el pasado." In: TOPOLSKI, J. História Econômica. Nuevos enfoques y nuevos problemas. Barcelona: Crítica. 1981. O estudo citado de Genovese é: 0 mundo dos senhores de escravos.

${ }_{17}$ ZARTH, Paulo, op. cit., p. 3-4.

18 SLICHER VAN BATH, Bernard. op. cit., p. 239.
} 
No Brasil, alguns historiadores produziram estudos sobre o mundo agrário do país, com base numa nova concepção de racionalidade econômica. ${ }^{19}$ Para estes autores, as queimadas (copiada dos indígenas), por exemplo, passaram a ser vistas pelos agricultores como uma atitude racional de uso da fertilidade natural dos solos virgens, numa situação de pequena densidade demográfica, que permitia o pousio da terra até sua recuperação (resiliência). Segundo esta análise, a principal obra utilizada como referência para esta concepção foi o livro de Ester Boserup, Evolução Agrária e Pressão Demográfica, onde o autor faz uma análise dos sistemas de cultivo tradicionais em diversos lugares do mundo demonstrando sua lógica e racionalidade própria, observadas as condições oferecidas pela natureza e as condições demográficas ${ }^{20}$. No caso brasileiro, um exemplo dessa influência foi analisado por João Fragoso na agricultura do Vale do Paraíba do Sul, onde os sistemas de cultivo, tido como arcaicos ou tradicionais, se mantiveram ao longo do tempo como resultado de um sistema agrário historicamente definido e não por simples ignorância, falta de conhecimento ou displicência dos produtores. ${ }^{21}$

De modo geral, as práticas rotineiras da agricultura em São Paulo eram atribuídas à ignorância dos lavradores nacionais, não apenas os pequenos, diga-se de passagem, que teriam aprendido tal sistema dos indígenas e dos africanos, e por comodidade, facilidade de acesso a terras novas, a economia e uso da mão de obra no curso do tempo seriam fatores para serem considerados na adoção e continuidade de tais métodos agrícolas no tempo. Visto assim, alguns ideólogos e defensores da imigração européia insistiam em trazer colonos da Europa para desenvolver a agricultura racional a partir de sua suposta capacidade de trabalho e de inovação tecnológica, bem como diversos meios de propagar as técnicas da moderna agricultura. ${ }^{22}$

Desta maneira, relatos criticando as práticas agrícolas adotadas pelos agricultores podem ser facilmente encontrados em centenas de fontes documentais desde, de pelo menos, o século XVIII no Estado de São Paulo. As críticas eram baseadas em comparação ao que era considerado tradicional e ao que era moderno ou não moderno. Pode ser destacado a partir da análise de documentos como os que são apresentados neste artigo, que as críticas ao sistema tradicional de cultivo eram feitas a partir da comparação com as técnicas modernas, baseadas na adubação e utilização de maquinários agrícolas.

\footnotetext{
${ }^{19}$ Entre eles podemos citar: CARDOSO, Ciro Flamarion Santana. Agricultura, escravidão e Capitalismo. Petrópolis: Vozes, 1979; LINHARES, Maria Yedda L. "Subsistências e Sistemas Agrários na Colônia: Uma Discussão." São Paulo: Revista Estudos Econômicos, IPE, USP, Volume 13, 1983; FRAGOSO, João Luis Ribeiro. "A Roça e as Propostas de Modernização na Agricultura Fluminense do Século XIX: O Caso do Sistema Agrário Escravista - Exportador em Paraíba do Sul". Revista Brasileira de História. (ANPUH) Vol. 6, №12, Março-agosto, 1986, pp. 125-126.

${ }^{20}$ BOSERUP, Ester. Evolução Agrária e Pressão Demográfica. São Paulo: Hucitec e Polis, 1987.

${ }^{21}$ FRAGOSO, João Luis Ribeiro. op cit.

22 HENRIQUES, Amilson Barbosa. op. cit. Através da leitura, por exemplo, do Congresso Agrícola de 1878 realizado no Rio de Janeiro, tais concepções e idéias são explicitamente defendidas. Cf. CONGRESSO AGRíCOLA, [1878]. Coleção de Documentos. Rio de Janeiro: Fundação Casa de Ruí Barbosa, 1988.
} 
Cabe ainda destacar que, no livro de Ester Boserup, o autor demonstrou que são falsas as tentativas de taxar os agricultores "tradicionais" de primitivos, pois, acredita 0 autor, as abordagens partem de princípios diferentes de análise, deixando de apreender a racionalidade inerente ao próprio sistema tradicional de cultivo, o qual obedece a uma lógica específica desenvolvida pelos agricultores em determinadas condições (econômicas, sociais, ambientais, etc). Sobre isso, Ester Boserup destacou que:

A crença geral de que a ignorância é a causa principal do uso de métodos de cultivos extensivos fez com que tanto os governos coloniais quanto os governos independentes se lançassem ansiosamente à instrução dos cultivadores primitivos, no que diz respeito ao uso de métodos de produção intensivo. ${ }^{23}$

Visto neste sentido, a aparente abundância de terras florestais ou virgens, nos dizeres e pensamentos de dezenas de autores e agricultores no passado do Brasil, deu origem à idéia de que as tais áreas eram ociosas ou mal exploradas, e que deviam sofrer exploração econômica e agrícola pelos lavradores nacionais. Na verdade, os pequenos agricultores e os indígenas utilizavam o sistema de pousio longo, onde a terra é deixada em descanso e se reflorestando naturalmente formando as chamadas capoeiras ou capoeirões, que nada mais são do que formações ecológicas secundárias ou terciárias, depois da primeira ou secunda utilização do espaço para a agricultura. ${ }^{24}$ Esse sistema de pousio possibilitava ao solo a renovação, se assim pode ser dito, das áreas utilizadas e desgastadas pela agricultura durante o tempo.

Ester Boserup, referindo-se ao continente africano, observou neste sentido que os

[...] colonizadores e funcionários coloniais europeus das regiões onde predominava 0 cultivo com alqueive longo ignoraram o fato de que estas terras em aparente desuso estavam, na verdade, sob pousio. Vastas extensões daquelas terras foram expropriadas para uso dos colonos e das companhias plantadoras ou foram declaradas reservas, onde não era permitido aos nativos abrir clareiras para o cultivo. Pensava-se que nenhum dano se causaria à população nativa, desde que lhes fosse deixada a posse das terras que estavam, na ocasião, sob cultivo. ${ }^{25}$

${ }^{23}$ BOSERUP, Ester. op. cit., p. 75. Ver: MUNARI, Lúcia Chamlian. Memória social e ecologia histórica: a agricultura de coivara das populações quilombolas do Vale do Ribeira e sua relação com a formação da Mata Atlântica. Dissertação (Mestrado em Ciências). Universidade de São Paulo. Instituto de Biociências, 2009. Nesta pesquisa, a autora analisa como viviam as comunidades quilombolas e os efeitos do método de plantio de coivara na Mata Atlântica, a capacidade de resiliência da floresta, os hábitos culturais e agrícolas num passado recente, porém ancestral.

24 Antônio Cândido faz um estudo sensivel sobre 0 aspecto da relação do pequeno agricultor com a sua pequena propriedade basicamente de subsistência. MELLO E SOUZA, Antônio Candido de. Os Parceiros do Rio Bonito. Estudo sobre o caipira paulista e a transformação dos seus meios de vida. $3^{\mathrm{a}}$ Ed. São Paulo: Livraria Duas Cidades, 1975.

${ }^{25}$ BOSERUP, Ester. op. cit., p. 16. No estudo de Lúcia Munari este aspecto das plantações camponesas, de pequenos agricultores isolados fica patente. MUNARI, Lúcia Chamlian. op. cit. 


\section{Modernidade e ciência em São Paulo}

O século XIX é conhecido como "a era da ciência". Aquele final de século representou 0 momento do triunfo da modernidade que era ambicionada por boa parte da população brasileira naquele período. Símbolos da modernidade, a velocidade e a rapidez eram os lemas daquele momento, onde o eixo Rio de Janeiro - São Paulo era o mais expressivo da cultura e da vida material da virada do século XIX-XX, sendo pólos centralizadores e difusores de modas e costumes europeus e norte-americanos. Para se ter uma ideia, na passagem do século o Rio de Janeiro era 0 $15^{\circ}$ porto do mundo em volume de comércio, superado na América apenas por Nova Yorque e Buenos Aires. São Paulo registrava em 1903-1904 um total de cerca de 1.200 navios de diversas nacionalidades desembarcando e embarcando mercadorias em seu litoral. ${ }^{26}$

Este era um momento, portanto, em que grande parte dos proprietários agrícolas e industriais, confiante no seu avanço e riquezas, viu na ciência a possibilidade de expressão de suas mais altas ambições. Tal qual uma revolução industrial sem fim, aqueles homens passaram a tentar domar a natureza a partir de uma miríade de invenções. Cada novo invento levava uma cadeia de inovações, que por sua vez abria perspectivas e projeções inéditas. Dos inventos fundamentais e importantes aos mais surpreendentes e inutilizados, das grandes estruturas aos pequenos detalhes, uma cartografia de novidades cobria os olhos daqueles homens, estupefatos com suas máquinas maravilhosas. ${ }^{27}$

As exposições universais passavam a demonstrar didaticamente o progresso e imaginar 0 futuro. As feiras e exposições nacionais e internacionais atingiram uma média de mais de 200 encontros anuais por volta de 1910-1913, sendo que o Brasil esteve representado em muitas delas. ${ }^{28}$ Assim como ressalta Almir P. Freitas Filho, as exposições divulgavam "os resultados do labor técnico e das conquistas científicas dos homens em relação ao domínio da natureza." Para este autor, as exposições além de funcionarem como uma amostragem muitas vezes parcial e incompleta do estágio econômico, técnico e cultural do país, apontavam também para suas carências, indicando desse modo, formas mais concretas de intervenção na realidade. ${ }^{29}$

\footnotetext{
${ }^{26}$ SÃO PAULO (Estado). Secretaria da Agricultura, Comércio e Obras Públicas. "Movimento marítimo." Relatório da Agricultura, apresentado ao Dr. Jorge Tibiriçá pelo Dr. Carlos Botelho, Secretário da Agricultura. 1904. São Paulo: Tipografia Brasil de Carlos Gerke. 1905. p. 165

27 Dezenas de invenções são aventadas em: COSTA, Angela Marques da; SCHWARCZ, Lilia Moritz. 1890-1914: no tempo das certezas. São Paulo: Companhia das Letras, 2000.

28 LOVE, Joseph L. A Locomotiva: São Paulo na federação brasileira 1889-1937. Trad. Vera Alice Cardoso Silva. Rio de Janeiro: Paz e Terra, 1982. p. 303-304.

${ }^{29}$ FREITAS FILHO, Almir Pita. "Tecnologia e escravidão no Brasil: aspectos da modernização agrícola nas Exposições Nacionais da segunda metade do século XIX (1861-1881)." Revista Brasileira de História, v.11 (22), mar-abr. 1991. p.7192.
} 
Era esse o momento das realizações, da efetivação de projetos de controle das intempéries naturais. Essa verdadeira "ideologia do progresso" e os novos avanços técnicos traziam a confiança de um domínio absoluto sobre a natureza e os homens. ${ }^{30}$

Em meio a esse ambiente, porém, civilização e modernidade convertiam-se em palavras de ordem, viraram instrumentos de luta e discussão, além de imagens de um ideal desejado. 0 Brasil entrava no século XX tão confiante nesse ideal como as demais nações do mundo: nada como imaginar que seria possível domesticar o futuro, prever e impedir flutuações financeiras, domar a natureza aos desígnios humanos. Sem dúvida esse é o tempo que aposto em verdades absolutas, pois científicas, em normas morais rígidas, na solução de todos os problemas imponderáveis, fiouse em modelos que distinguiam, de forma insofismável, o certo do errado. ${ }^{31}$ Não é à toa que tenha sido considerado por um historiador como um século muito longo. Como afirmou Eric J. Hobsbawn, para além das datas que estancam os marcos (história factual), o século XIX teria terminado apenas no ano de 1914. Foi, então, e com a realidade da Primeira Guerra Mundial, que se pôs fim a esse "tempo das certezas". 32

No começo do século XX acreditava-se, sobretudo, nos confortáveis valores de um contexto em que certas verdades religiosas e a lealdade à pátria estavam na ordem do dia. 0 mundo estava menor diante do desenvolvimento dos transportes de massa, como ferrovias e navios a vapor. Não é à toa que os grandes símbolos daquele momento fossem a luz e a velocidade.

Neste contexto, o caráter global da economia capitalista consolida-se no século XIX, atingindo fronteiras intocadas e descortinando barreiras geográficas, políticas, sociais e econômicas. A raiz dessa dinâmica expansionista pode ser vinculada à Revolução Industrial de meados do século. Esse verdadeiro surto da economia industrializada se baseou em três elementos básicos: o ferro, o carvão, e as máquinas a vapor. No entanto, é o momento seguinte que mais nos interessa. Trata-se de pensar nas decorrências da Segunda Revolução Industrial - também conhecida como Científico/Tecnológica -, ocorrida, sobretudo, depois da década de 1870. Essa revolução levou à aplicação das recentes descobertas científicas aos processos produtivos da economia, possibilitando o desenvolvimento de novas fontes de potenciais energéticos, como a eletricidade e os derivados do petróleo, assim como a hidráulica e o carvão, que geraram mudanças

\footnotetext{
30 SEVCENKO, Nicolau. Literatura como Missão: tensões sociais e criação cultural na Primeira República. 2. ed. São Paulo: Companhia das Letras, 2003.

31 Idem ibidem.

32 HOBSBAWM, Eric J. Era dos Extremos: o breve século XX: 1914-1991. São Paulo: Companhia das Letras, 1995. A expressão é de Angela Marques da Costa e Lilia Moritz Schwarcz no livro já citado.
} 
de impacto nos mais diferentes setores: na indústria, biologia, microbiologia, química aplicada, farmacologia, medicina, na higiene e profilaxia, engenharia entre outros. ${ }^{33}$

Foi em meio a esse processo que apareceram os veículos automotores, os transatlânticos, os aviões, o telégrafo, o telefone, a iluminação elétrica, uma extensa variedade de utensílios domésticos, a fotografia, o cinema, a radiodifusão, a televisão, construções grandiosas da engenharia e seus elevadores, as escadas rolantes e os sistemas metroviários, os parques de diversões elétricos, as rodas-gigantes e as montanhas-russas, a anestesia, a penicilina, 0 estetoscópio, o medidor de pressão arterial, a dinamite, os processos de pasteurização e esterilização, os adubos artificiais, o papel higiênico, a escova e a pasta de dentes, o sabão em pó, os refrigerantes com gás, o fogão a gás, as comidas enlatadas, as cervejas engarrafadas, a aspirina, e anti-ácidos. Era o chamado "mundo moderno" que surgia na frente dos olhos das pessoas.

No entanto, o progresso histórico dentro do capitalismo é bastante ambíguo. Essa verdadeira escalada na produção dos países ocidentais, fundamentalmente, levou, por sua vez, a disputa por matérias-primas disponíveis no mundo, bem como, à ampliação do mercado e o fenômeno conhecido como neocolonialismo ou imperialismo. Fenômeno esse que acarretou uma nova divisão internacional de áreas não colonizadas - ou, ainda, a novas relações de dependência em áreas de passado colonial. ${ }^{34}$

A despeito da sua feição de triunfo e progresso, a belle époque tinha várias faces, como a pobreza e a miséria em franca expansão, ao lado da grande concentração de riqueza disposta a poucos elementos da massa da população. ${ }^{35}$

\footnotetext{
De qualquer maneira, de forma mais ou menos direta é possível perceber o ideário de uma época que, volta e meia, colocava em evidência as conquistas científicas alcançadas pelo homem, bem como seus efeitos contrários. Mesmo com tantas certezas, há sempre a apreensão diante do que não se pode planejar com certo grau de precisão. Utopias trazem certezas e, também, muitas dúvidas. 0 mundo que se debruçou sobre 0 século XX mostrou sua face mais idílica e otimista, mas não conseguiu esquecer o temor do porvir. Ainda assim, modernidade combina com avanço e - nesse caso - progresso. Era essa a face brilhante do teatro da modernidade que o Brasil queria acompanhar, já que não era possível tomar a dianteira. ${ }^{36}$
}

Foi neste contexto que diversos intelectuais, grandes e poderosos fazendeiros do chamado Oeste Paulista, agrônomos formados em famosas escolas agrícolas da Europa, como Grignon e Montpellier na França, Hohenheim na Alemanha e o Institut Agrícola de L'État de Gembloux, na

\footnotetext{
33 Idem ibidem.

34 Idem. A Era do Capital. Rio de Janeiro: Paz e Terra, 1975.

35 Sobre isso ver: SEVCENKO, Nicolau. Literatura como Missão. op. cit.

${ }^{36}$ COSTA, Angela Marques da; SCHWARCZ, Lilia Moritz. op. cit., p. 25.
} 
Bélgica, advogados, políticos e outros, queriam trazer para a agricultura paulista o que de mais moderno era feito e utilizado em países do Velho continente e nos Estados Unidos, no intuito de modificar sua feição, sua característica. Queriam produzir muito e barato, produzir diversos produtos, com reduzida, porém qualificada mão-de-obra, e com sabedoria científica, por isso o seu "nome": agricultura científica, racional, moderna, nas palavras daquelas pessoas. Mas as propostas de modernização agrícola não foram acompanhadas de poucos debates e contradições ${ }^{37}$.

A partir da década de 1870, São Paulo tornava-se um lugar privilegiado das transformações socioeconômicas, urbanísticas, físicas e demográficas. Bem no meio da prosperidade crescente da lavoura cafeeira e das tensões ligadas ao final da escravidão no país, a cidade se transformava de forma acelerada na "metrópole do café". Todo esse conjunto de fatores implicou, por sua vez, alterações profundas nas funções e espaços da cidade, em favor de um maior controle e racionalização, de modo a assegurar para São Paulo o importante status de entreposto comercial e financeiro privilegiado para as relações entre a lavoura cafeeira e o capital internacional. ${ }^{38}$

São Paulo também acompanhou as diversas reformas progressistas do momento, como por exemplo, a reforma urbanística que começa em 1872, com o governo de João Theodoro Xavier de Mattos, para poder receber os grandes proprietários e capitalistas da então mais próspera província do Brasil. E, foi isso mesmo que aconteceu ancorado na necessidade de ampliação da comunicação de transporte com 0 interior para o escoamento da produção de café e 0 deslocamento de pessoas. Segundo Odilon Matos, em 1870 a Província de São Paulo possuía 830 mil habitantes, 60 milhões e 462 mil pés de café e 139 quilômetros de ferrovias. Já em 1900 o Estado de São Paulo suportava 2 milhões e 279 mil habitantes, mais de 220 milhões de pés de café, e 3.373 quilômetros de ferrovias. ${ }^{39}$ Não era pouco.

Neste sentido, o que nos interessa enfatizar é: quais foram as propostas de modernização da agricultura no período? O que foi pensado e feito em matéria agrícola? Daremos aqui algumas delas.

\section{Moderna agricultura: crítica à agricultura tradicional e a Revista Agrícola}

A virada do século (XIX-XX) foi cenário de discussão bastante acirrada sobre a técnica entre os cafeicultores e lavradores. Não se sabia ao certo se seria proveitoso introduzir a mecanização no cultivo. Ou seja, em lugar da considerada "primitiva enxada", valeria à pena utilizar as novas máquinas de tração animal, os instrumentos aratórios? Aqueles que eram favoráveis

\footnotetext{
${ }^{37}$ HENRIQUES, Amilson Barbosa. op. cit. Onde são abordadas alguns desses debates.

38 LEMOS, Carlos. Alvenaria Burguesa. São Paulo: Nobel, 1989.

39 MATOS, Odilon Nogueira de. Café e Ferrovias: A evolução ferroviária de São Paulo e o desenvolvimento da cultura cafeeira. 4 ed. Campinas: Pontes, 1990.
} 
alegavam que cada arado valia por mais de uma dezena de trabalhadores (ou colonos), e tinha por vantagem não remeter dinheiro para o estrangeiro e nem sangrar o Tesouro nacional com despesas de transporte com a imigração, e também não reclamavam e nem geravam conflitos e discussões às vezes com término violento no interior dos estabelecimentos rurais. ${ }^{40}$

Costumava-se dizer, por outro lado, que a redução de trabalhadores na lavoura causaria problemas na hora da colheita, o que era contestado por alguns entusiastas que eram a favor da mecanização agrícola. Na opinião dos mais céticos ou realistas, com a máquina poderia haver descontrole das lâminas do arado, ou que os aparelhos não eram apropriados à cultura do cafeeiro, pondo em risco por isso o corte e prejudicando as raízes da planta, além de não se chegar às áreas montanhosas - essa última, uma crítica clássica no Brasil que via nesse motivo o porquê dos agricultores não fizesse uso dos instrumentos aratórios. ${ }^{41}$

Por sua vez, os trabalhadores ou imigrantes temiam as inovações, já que não poderiam plantar seu milho e feijão nas ruas dos cafezais devido às máquinas, e o desemprego seria certo, fato esse também contestado por diversos entusiastas, que consideravam que o fazendeiro poderia deixar o trabalhador cultivar seus alimentos em uma área especialmente dedicada a isso, ou que estes fossem estabelecidos em núcleos coloniais (particulares ou do Estado), onde na época das colheitas eles seriam chamados ao trabalho nas grandes propriedades novamente (por isso, alguns especialistas chamavam estes núcleos de "viveiros de trabalhadores"). As outras operações agrícolas (excluindo aqui a colheita) seriam feitas com pouco uso de mão de obra, visto que o uso dos instrumentos aratórios modernos economizariam grande parte da força de trabalho empregada até então, devido a isso, os trabalhadores poderiam tocar seus pequenos estabelecimentos rurais (lotes) a seu bel prazer e, que também seria condicionada ao trabalho dos "aparelhos aperfeiçoados", instrumentos aratórios em geral, que facilitaria o trabalho diário (pois era puxado por animais de tração) economizando tempo e trabalho físico, aumentando a produção e sua qualidade, economizando espaço (agricultura intensiva, portanto) e tratando (lidando ou poupando) o solo do desgaste natural da utilização agrícola observada historicamente no país. ${ }^{42}$

É neste contexto que surgiu uma das primeiras publicações sobre agricultura em São Paulo no período republicano: a Revista Agrícola. Órgão da Sociedade Pastoril e Agrícola. A Sociedade

\footnotetext{
40 Sobre 0 trabalho nas fazendas, repressão, violência, miséria aos trabalhadores rurais. Cf. STOLKE, Verena. Cafeicultura: Homens, Mulheres e Capital (1850-1980). São Paulo: Brasiliense, 1986.

${ }^{41}$ HOLANDA, Sérgio Buarque de. "Persistência da lavoura do tipo predatório." In: Raízes do Brasil. São Paulo: Companhia das Letras, 1995. p. 66-70.

42 Ver: HENRIQUES, Amilson Barbosa. op. cit. Onde é destacado que, apesar de existente, as pesquisas sobre agricultura relacionando a modernização técnica com mão de obra imigrante, quantidade de terras disponíveis, entre outros assuntos relacionados, não é extensa. Diversos autores tocaram no tema, contudo não o desenvolveram profundamente. SALLUM JR, Brasílio. Capitalismo e Cafeicultura: Oeste Paulista - 1888-1930. São Paulo: Duas Cidades, 1982, destaca que os agricultores não aderiram a técnicas modernas de cultivo no período por causa de fatores de produção: terra, trabalho e capital, principalmente.
} 
Agrícola e Pastoril surgiu em 30 março de 1895 na capital do Estado, na Rua Líbero Badaró, n. 117, sediada em um dos salões do Club da Caça e Pesca 43 por iniciativa de Domingos J. N. Jaguaribe (1848-1926) seu fundador, político e grande fazendeiro, ativo propagandista da modernização da agricultura e, também, por iniciativa de grandes fazendeiros residentes em São Paulo, como Carlos José de Arruda Botelho (1855-1947), filho primogênito de Antônio Carlos de Arruda Botelho (18271901), conde do Pinhal, Bernardo Avelino Gavião Peixoto (1829-1912) e Luiz Vicente de Souza Queiroz (1849-1898).44

Entre os temas que veicularam nas páginas deste periódico (alguns deles muito bem estudados pela bibliografia especializada), estavam os mais candentes da época, quais sejam: os impasses da imigração, a difícil implantação de núcleos coloniais pelo governo e por particulares, o êxodo dos colonos das áreas e fazendas produtoras, a necessidade sempre presente de diversificação da agricultura e suas conseqüências na economia e vida da população em geral, o fracionamento da grande propriedade e as dificuldades com relação à mecanização da lavoura em substituição à agricultura que os diversos autores no periódico consideravam como atrasada, rotineira ou tradicional.

No reboque de tais propostas esteve presente, por diversas vezes, o destaque da agricultura intensiva, a agricultura considerada racional, que na visão de alguns deles significaria mais alimento à população, o mais barato possível, bem como a fixação do colono a terra em pequenas propriedades, a conservação da floresta e do seu solo para que as futuras gerações (era essa a expressão usada por diversos autores) pudessem usufruir de um patrimônio que já era olhado como um recurso e que poderia um dia acabar. 45

No retorno dos estudos na Europa, como de praxe na época, os jovens herdeiros de vastos patrimônios materiais, formados em direito, engenharia, medicina e também em agronomia não

43 O Club da Caça e Pesca foi fundado em 1892 por Domingos Jaguaribe em São Paulo, "com o intuito não só de ser um ponto de reunião dos apaixonados desses exercícios tão úteis e salutares a nossa existência, como também para pugnar pela criação de leis sobre o assunto" SOBRINHO, José Leite da Costa. "Caça e Pesca." Revista Agrícola, ano I, n. 2. 1895. p. 21-22. Segundo Warrean Dean, o Club da Caça e Pesca foi criado por pessoas abastadas em sua maioria, e com ligações com o PRP, que estavam cada vez mais preocupadas com o rápido processo de urbanização provocado pela imigração em massa, e pela modificação do clima das cidades paulistas. Devido ao desaparecimento da natureza no centro da capital algumas pessoas foram levadas a criar tal clube, "para evitar a matança de urubus, aves canoras e outras espécies úteis. Conseguiram obter a aprovação de uma lei estadual, aparentemente dirigida de maneira dissimulada aos imigrantes italianos - cujo costume de caçar pássaros para alimentação era um dos muitos que a classe média nativa desdenhava -, proibindo matar qualquer pássaro durante a estação de acasalamento." DEAN, Warrean. A Ferro e Fogo. op. cit., p. 246. A lei aludida por Dean pode ser: Lei Municipal n. 68, de 16 de novembro de 1893, que regulou questões sobre a caça, a pesca e a navegação na cidade de São Paulo.

44 REVISTA AGRÍCOLA. "Indústria Pastoril - A Indústria Pastoril em São Paulo - Seu Presente e seu Futuro - A Sociedade Pastoril e Agrícola - A 'Revista Agrícola'”. N. 1, ano I, 1895. p. 1-5.

45 Para Robert de Moraes, o uso do conceito de recurso natural aparece intrínseco a uma dada sociedade, que tem a função de discriminar alguns elementos da natureza para que pudessem ser utilizados em processos produtivos e gerais. Assim, a elaboração e uso deste conceito, no século XIX, só pode ser entendido como parte dos mecanismos de produção e reprodução do capitalismo brasileiro. MORAES, Carlos R. de. Meio Ambiente e Ciências Humanas. São Paulo: Annablume, 2005. p. 101-103. 
possuíam apenas visões políticas e ideológicas diferentes das dos seus pais e avôs em relação ao escravismo, ao Império, mas, sobretudo, desejavam ver a modificação da agricultura considerada tão atrasada que nem o nome de agricultura deveria em função das práticas agrícolas aqui vislumbradas. Ao que parece, este ambiente de mudanças radicais, na política, sociedade, cultura, intelectualidade, etc., foi um movimento bem amplo na sociedade do período do final do século XIX e início do século $X X .46$

Neste sentido na crítica à agricultura considerada atrasada e irracional é que surgem na Revista Agrícola as propostas de sua modificação. As críticas de diversos autores, observações e opiniões recaiam na chamada Agricultura Tradicional (irracional, rotineira e atrasada eram os termos utilizados para caracterizar essas práticas agrícolas), praticada desde os tempos coloniais. Para àqueles autores, com a substituição da agricultura praticada, o país poderia alçar economicamente ao patamar dos países mais industrializados e progressistas do mundo, como a França, a Inglaterra e os Estados Unidos.

Desta perspectiva, algumas propostas relativas aos métodos de cultivos dos solos, 0 emprego de adubos químicos e a conservação das florestas e de seu solo, foram divulgados na Revista Agrícola paulista e que foi objeto de estudo em dissertação de mestrado são apresentadas neste artigo 47 .

Na Revista Agrícola de novembro de 1895, Guilherme Schüch Capanema48 (1824-1908) escreveu sobre as Queimadas. Advertia 0 autor que as florestas na América sempre foram "rapinadas" pelos homens, mas que com o advento das lavouras de exportação, e a multiplicação dos lavradores durante os séculos, a cultura do solo tornou-se cada vez mais predatória. Destacava que, com o desenvolvimento das ciências, os homens teriam necessariamente que fazer um aproveitamento mais racional do solo cultivado. Encantado pela época que vivia, de descobertas e inovações em diversas áreas do conhecimento, salientou Capanema:

[...] os homens deixaram de ser escravos cegos das idéias seculares, principiaram a compreender as leis da natureza, investigá-las e aplicá-las, acumularam com paciência e aturado trabalho, matéria para os assombrosos recursos de que hoje dispomos, cuja simplicidade admiramos, porém que para seu desenvolvimento careceram mais de um século: assim o vapor $\mathrm{e}$ a eletricidade. 49

\footnotetext{
${ }^{46}$ É o que sugere Iraci Salles com o advento do PRP em São Paulo: SALLES, Iraci Galvão. Trabalho, Progresso e a Sociedade Civilizada: o Partido Republicano Paulista e a Política de Mão-de-Obra (1870-1889). São Paulo: Hucitec, 1986.

${ }^{47}$ HENRIQUES, Amilson Barbosa. op. cit. São utilizados apenas alguns autores, mas no periódico são dezenas de autores e centenas de artigos que trataram dos temas nesta ocasião apresentados.

48 Sobre Capanema ver: FIGUEIRÔA, Silvia Fernanda de Mendonça. "Ciência e tecnologia no Brasil Imperial Guilherme Schuch, Barão de Capanema (1824-1908)." Varia História. V. 21, n 34, p. 437-455, 2005.

${ }^{49}$ CAPANEMA, Guilherme S. "As Queimadas." Revista Agrícola, ano I, n. 6, 1895. pp. 91-93. p. 91. A grafia das fontes utilizadas foi corrigida ao português atual.
} 
Devido ao progressivo desenvolvimento humano nas ciências diversas, nos materiais, na química e biologia, por tudo isso, Capanema tinha a esperança de "um dos resultados mais modestos, é sem contestação o mais importante, pois que nos garante os meios de viver, que os nossos antepassados tendiam a destruir". Referia-se à agricultura, que para ele era um

[...] sistema de rapina, nós nos apoderamos do que a natureza nos oferece, mas não nos lembramos de the pagar aquilo de que tiramos proveito, e que esgotamos os depósitos que deveríamos manter sempre bem sortidos ${ }^{50}$.

Demonstrou Capanema em seu artigo, que apesar de viver um momento impar dentro da história mundial, um momento de progresso e de descobertas científicas, a despeito disso os homens no Brasil não davam conta do valor de uma "bela floresta com frutos alimentícios", preciosas matérias medicinais, matérias-primas para a indústria, e que constam de água, ácido carbônico, azoto, sais de potássio, cálcio e magnésio, acido fosfórico-sulfúrico, etc.-, elementos importantes ao corpo humano e na agricultura - acumulados lentamente nestas árvores durante décadas ou mesmo séculos..$^{51}$

O que queria dizer é que o agricultor não aproveitava de todo o potencial que natureza oferecia ao homem. Não sabia ainda aproveitar aquilo tudo. Ao contrário: "Derrubamos as matas e Ihe atacamos fogo, a água, o ácido carbônico e o azoto lá se vão pelos ares, ficam nas cinzas os sais alcalinos solúveis na água, e sais de terra alcalinas pouco, os insolúveis." Princípios químicos e orgânicos tão caros ao aproveitamento da agricultura. ${ }^{52}$

Desta maneira, sobre o uso histórico da queimada na agricultura para abertura de campos ao cultivo do solo, ressaltava Capanema que se após a queimada das florestas ou capoeiras não viesse uma chuva fina, "criadeira", como a chamavam os lavradores, os sais solúveis penetravam no solo, onde eram na maior parte retidos pela terra. Porém, se caísse uma chuva torrencial estes princípios essenciais seriam levados pela enxurrada, e não enriqueceriam o terreno para produção de "vegetais vorazes", como os cereais que "são os veículos em que pelo seu consumo adquirimos o fosfato de cal para formação dos ossos do nosso corpo e sais que entram na composição da nossa carne, etc. Porém, isto só não basta; precisamos ainda do azoto, que os vegetais nos proporciona em forma de albuminas, proteínas, etc."53 Para ele, algumas plantas tinham a propriedade de absorver o azoto (nitrogênio) do ar, a maior parte porém, o recebiam do solo onde

\footnotetext{
50 Idem ibidem. P. 91. Sortidos no sentido da necessidade do agricultor manter o solo de sua propriedade sempre fértil (com adubação artificial), para que sua produção fosse boa e o solo poupado do desgaste com o tempo.

51 Idem ibidem. P. 91-92

52 Idem ibidem. P. 91.

53 Idem ibidem. P. 91.
} 
as raízes o encontravam em forma de nitratos, "transformação lenta das folhas, lenho e raízes". Mas "pelas queimas destruímos imensa quantidade de fontes de azoto em condições de ser assimilado" pelos cultivos agrícolas, numa advertência para o desperdício do nitrogênio no processo de queimada e abertura de terrenos para a agricultura.

Advertia também que não era apenas dos vegetais que os homens retiravam os alimentos necessários ao corpo humano, sua nutrição geral. Os homens recorriam também à alimentação com carne de outros animais que vivem de pastos. Segundo o autor, os pastos cobriam vastas extensões de terreno, mas que não eram perenes, pois, a maior parte de sua vegetação era anual, excluindo o que não era consumido seco (as forragens para animais de criação).

Então entendeu o selvagem [alusão a coivara praticada pelos índios] que devia queimar o capim seco afim de nascer com maior vigor a planta nova. Há nisso uma boa razão de ser: libertam-se os sais nutritivos contidos nessa erva em condições insolares na maior parte, e espalham-se em formas solúveis sobre o solo, onde parte penetra, e muita é levada pelas enxurradas, indo alimentar plantas aquáticas em rios, lagos e mares distantes. ${ }^{54}$

Apesar disso, segundo constatou Capanema: "A conseqüência destas queimadas repetidas é empobrecimento, esterilização do terreno do que por toda a parte encontramos provas." 55 . Neste sentido, uma paisagem saltou aos seus olhos quando fez uma viagem ao Paraná, nos "afamados Campos Gerais", que:

[...] onde se dizia abundar o celebrado capim mimoso; tive curiosidade de vê-lo, mas só existia ainda em raros vales, tendo a maior parte desaparecido, não só pela esterilização, mas porque vai formando moitas não tem serapilheira de raízes, cuja camada, como acontece ao barba de bode que substitui, formando densas touceiras e pouco prestando para o pasto.

Nesses lugares não vi samambaia, que anos depois encontrei estendendo-se com rapidez. 56

Em contraposição ao que era praticado no Brasil, sem fiscalização e, tão pouco, leis para infringir as queimadas e a mudança de hábitos considerados como nocivos economicamente, Capanema destacou que havia recebido de uma biblioteca em Curitiba um livro sobre os Estados Unidos, "país de ampla liberdade, onde a pessoa do cidadão é inviolável, senhor inteiramente de seus atos", e depois de ter lido com atenção, viu "que apesar dessas garantias havia proprietários

\footnotetext{
54 Idem ibidem. P. 91.

55 Idem ibidem. P. 91.

56 CAPANEMA, Guilherme S. op. cit., p. 91. Serrapilheira: Camada de folhas, galhos, etc., de mistura com terra, que cobre o solo da mata. Ou designação comum às pequenas raízes que surgem à flor da terra. É a matéria orgânica depositada no solo por séculos pela floresta. Também pode ser considerada como húmus. Algumas espécies de samambaias eram encontradas em terrenos desgastados e pouco férteis depois de sucessivos usos e conseqüente abandono.
} 
de campos que não tinham a liberdade de dispor a seu talento de sua propriedade, havendo uma lei que os punia com pesada multa e cadeia quando se lembrasse de por fogo aos seus campos de criações nos vastos pampas (patries) americanos." 57

O liberalismo norte-americano era então visto sob o bem comum, da sociedade, e não apenas dos particulares. E não era apenas isso. $O$ exemplo norte-americano deveria ser imitado em diversos aspectos no Brasil, como destacou Capanema:

\begin{abstract}
É que os americanos, que nos jactamos de imitar, têm, além de muitas qualidades que nos faltam, muito bom senso, entenderam que deviam criar a cada canto comissões permanentes exclusivamente incumbidas de estudar borboletas, carrapatos, piolhos de plantas e dos bichos, caracóis, mofos, e quanta mais praga (que consome 25 ??? da produção agrícola do trabalho do homem, tributo que o mais despótico governo não se anima a impor.) além disso estudam composição de terrenos, suas alterações, melhoramentos, etc. .8
\end{abstract}

Segundo havia lido, essas comissões americanas verificaram que a queima dos campos empobreciam o solo em proporções cada vez maiores e propuseram que, por lei, se multasse 0 cidadão que quisesse voluntariamente sacrificar seus recursos, e, além disso, o fizesse refletir sobre seu ato na cadeia. Era a ciência a serviço da agricultura que pedia o autor, e leis que valorizassem os recursos naturais, e instruíssem os homens a praticarem uma agricultura mais racional utilizando os Estados Unidos como o exemplo a ser imitado (mas não transladado).

Seguiu o autor dissertando sobre experimentos de cientistas europeus sobre a composição química do solo, bem como, sobre adubos químicos e naturais que seriam necessários a reposição dos seus nutrientes. No artigo, Capanema destacou que havia feito, ele próprio, embasado nos experimentos do diretor do Instituto Agronômico de Campinas, Franz Josef Wilhelm Dafert (18871897), experiências com adubação. Apesar dos testes e experimentos de Capanema, ao que parece, terem sido por algumas vezes de resultado frustrante, chegou a um bom resultado e combinação de adubos para utilização nas terras, e para os lavradores fazerem uso ou terem como exemplo.

Segundo ele, depois de demonstrar as experiências de alguns cientistas - europeus e de Dafert, no Instituto Agronômico -, provaram, em sua visão, o quanto seriam nocivas as queimadas aos solos e seus nutrientes, o quanto era perdido devido a esse procedimento, o autor salientou que era preciso "sobretudo entre nós (homens de ciência preocupados com agricultura) procurar em um meio de habilitar, sobretudo o pequeno lavrador e seus camaradas que muitas vezes nem ler sabem, a empregar com acerto os ingredientes nutritivos na terra". A seu ver, os agricultores e

${ }^{57}$ Idem ibidem. P. 91. Grifo entre parênteses do original.

${ }^{58}$ Idem ibidem. p. 91-92. Grifo entre parênteses do original. 
trabalhadores não tinham conhecimento suficiente sobre os produtos químicos para a adubação do solo, pois, "custa entrar-lhes na cabeça (dos lavradores) a compreensão do fosfato e superfosfato de cal ou de potássio, nitrato, sulfato disto ou daquilo, e quando decorem os nomes, não se evitam as trocas".

Contudo, mesmo o próprio Capanema cometeu esse erro (confusão na mistura de componentes para adubação química do solo), atestando que a utilização, e antes disso, as experiências com adubos químicos em São Paulo eram incipientes, pois um intelectual como Capanema ainda não estava familiarizado com os insumos que tinha em mãos para a realização dos seus intuitos científicos e agrícolas:

\begin{abstract}
Desta fui vítima [confusão com os compostos químicos para adubação], evitei-o de modo a poder confiar a composição de adubos ao mais ignorante trabalhador; eu tinha cada um dos sais em barris com cores diferentes, e as minhas receitas eram: "tantas canecas do barril vermelho, tantas do verde e untada com tantas quartas de terra." Isto nada tinha de aristocraticamente científico: era, porém, muito democraticamente prático.

Cheguei mesmo a formular a receita com riscos de diversas cores cada um representando uma caneca do respectivo ingrediente. ${ }^{59}$
\end{abstract}

Destacava que estes foram os passos e experimentos que havia seguido e que deu (Capanema) publicidade na Revista para que o agricultor também pudesse utilizar como resultado de seus experimentos:

1. Enterre cisco de capina, resíduos de toda espécie, e manipule;

2. Prepare diversos caixões contendo terra com esse cisco, e em cada um adicione alguma fórmula dos ingredientes [dos adubos químicos].

3. Quando pronto, plante nessas diversas caixas uma muda do vegetal que quer cultivar;

4. Coloque os caixões juntos, regue-os todos ao mesmo tempo e com a mesma quantidade de água;

5. Acompanhe o crescimento de suas plantas, observe qual a fórmula (até marcada nos caixões com os riscos de cor) que dê o melhor resultado, e a aplique à sua plantação;

6. Não espalhe simplesmente o adubo na superfície do terreno sobretudo no inclinado, como muitos aconselham. Vindo uma garoa demorada isto aproveita, mas chuva grossa leva todo estrume embora. 60

Não esquecendo que seria sempre conveniente misturar o adubo com a terra, ou fazer regos ou covas em torno da planta, lançando dentro destas, porções adequadas do adubo "excesso é prejudicial - cobri-lo com terra." E, no final do artigo, Capanema enfatizava que não existiam fórmulas prontas de adubos, mas que todos os detritos de uma propriedade rural deveriam

\footnotetext{
${ }^{59}$ CAPANEMA, Guilherme S. op. cit., p. 93. Destaque entre aspas do original.

${ }^{60}$ CAPANEMA, Guilherme S. op. cit., p. 93, grifo nosso. Referência para cisco de capina: Pó ou miudezas de carvão. Ou o que se obtinha com o procedimento da varredura dos campos cultivados. Tudo o que se obtinha de resíduos dentro de uma propriedade agrícola: cinzas de queimas diversas, do fogão, do pasto; urinas e excremento de diversos animais, etc., deveriam ser usados para a adubação.
} 
ser aproveitados como adubo na lavoura, nada deveria ser descartado: - "Assim cada um se guiará pela própria experiência."

A opinião básica contida neste artigo de Capanema era a opinião também de dezenas de outros autores que escreveram na Revista Agrícola em todo o período da publicação61. As queimadas deveriam ser evitadas. O solo deveria ser mais bem aproveitado no tempo e espaço, aumentado a produtividade das culturas em sua qualidade e quantidade (produzir muito e barato era o lema daqueles intelectuais), com a utilização de adubos, fossem eles químicos ou naturais, ou a combinação dos dois, se servindo também dos instrumentos aratórios (mecânicos).

Naquela época, algumas pessoas estavam realizando experiências com 0 solo, principalmente dos cafezais. ${ }^{62}$ Os compostos mais analisados eram os fosfatos de cal, os superfosfatos, nitratos diversos, e outros produtos. A maioria dos produtos químicos que eram vislumbrados como adubos provinham do exterior, e eram demasiadamente caros aos agricultores em geral e principalmente aos pequenos agricultores.

Luiz Vicente de Souza Queiroz (1849-1898)63 foi um dos defensores da utilização dos adubos químicos naquele momento na agricultura. Segundo ele, em Ipanema, interior de São Paulo, havia uma reserva grande de calcário que poderia servir para a exploração dos fosfatos necessários a adubação do solo paulista à agricultura, senão para todo o Brasil64. Em suas palavras:

\begin{abstract}
Realmente não há povo tão pouco prático e tão pródigo como o povo brasileiro; importamos milhares de toneladas de fosfato de cal, que é pago a razão de $300 \$ 000$ por tonelada pouco mais ou menos, quando a poucas horas desta cidade (São Paulo), em Ipanema, existem soberbas jazidas desta matéria fertilizante, que poderia, por não ser distante do porto de Santos e estar junto à estrada de ferro, fornecer a todo o Brasil um estrume artificial que faria não somente dobrar a produção das plantações já existentes como nos habilitaria a utilizarmos com grande vantagem as terras gastas e inferiores, pondo-nos em posição de produzir gêneros alimentícios, que hoje nos vem em tão grande escala do estrangeiro e cujo valor monta em muito mais de cem mil contos. ${ }^{65}$
\end{abstract}

Alertava Vicente Queiroz que os paulistas poderiam produzir o seu próprio insumo, ou ao menos, uma de suas bases principais, o fosfato de cal, a partir da exploração da chamada "jazida de Ipanema", economizando na importação daquele produto, facilitando o acesso e tornando-o mais barato ao maior número de lavradores possível, visto o barateamento que uma produção nacional, ou paulista, poderia suscitar. Em sua opinião, o governo deveria o quanto antes arrendar, explorar

\footnotetext{
61 HENRIQUES, Amilson Barbosa. op. cit.

62 MELONI, Reginaldo Alberto. op. cit.

${ }^{63}$ Fundador da Escola Agrícola Prática "Luiz de Queiroz", hoje a conhecida Escola Superior de Agricultura Luiz de Queiroz (ESALQ-USP). Para saber mais sobre essa instituição, ver: PERECIN, Marly Therezinha Germano. Os Passos do Saber: a Escola Agrícola Prática Luiz de Queiroz. São Paulo: Editora da Universidade de São Paulo, 2007. A formação dessa escola e do ensino agrícola em particular, fazem parte do mesmo contexto aqui analisado.

640 minério nessa área encontrado seria a apatita.

65 QUEIROZ, Luiz Vicente de Souza. "Fosfato de Cal." Revista Agrícola, ano I, n. 8, 1895, pp. 126-127. p. 126.
} 
ou vender aquelas "ricas jazidas" e, em caso algum deveria mantê-la inexplorada por mais tempo, "pois hão de contribuir forçosamente para debelar a nossa crise financeira [...]", - lembrando da crise cafeeira e monetária debelada em 1895-96 -, "[...] nos poupando a vergonha de ser o Brasil o único país novo que importa em tão larga escala gênero alimentício; assim muito melhorariam as nossas finanças, o que viria também auxiliar a consolidar nossas instituições, porque com boa finança é muito mais fácil fazer boa política". 66

A preocupação de Queiroz era recorrente aos autores da Revista Agrícola: como poderia um país como o Brasil, um Estado como o de São Paulo, farto em terras férteis ou passíveis de exploração agrícola, não produzir alimentos para o seu próprio sustento?! De fato, o Brasil, e não apenas São Paulo, importava diversos gêneros alimentícios como arroz, trigo e outros, e isso durante muito tempo. ${ }^{67}$ Por exemplo, em 1903, apenas em São Paulo, a exportação do que chamou o Secretário de Agricultura de "artigos destinados à alimentação e forragens", alguns deles que poderiam ser produzidos no próprio Estado, custaram com importação 33.295:799\$. 68

Não obstante, havia também críticas ou observações quanto ao uso sem métodos, ou poucas técnicas e conhecimentos quanto à compra, manipulação, quantidades, e outros, dos adubos químicos, como advertiam alguns autores pesquisados. Segundo um artigo na Revista Agrícola, as vantagens do uso da cal na agricultura era há muito tempo conhecidas, "o que não quer dizer, todavia que a sua aplicação se fizesse, tanto quanto o estão reclamando os terrenos faltos [no sentido de carentes] daquele elemento de vida."69

Advertia o autor, que direta ou indiretamente, a cal "concorre", era extremamente importante para algumas das funções essenciais da fisiologia vegetal. "É não só alimento, mas converte em alimentação muitas das matérias, que existem inertes no solo". Para G.P., estaria provado pela ciência naquele momento que os vegetais, "que se empregam na arte culinária, e igualmente as frutas, não tem tão boas qualidades, tão delicado sabor, se o terreno onde foram produzidas se achar pobre de cal". Devido a isso, segundo ele:

Os lavradores fazem em geral grande despesa com adubos e não colhem resultado correspondente, por que não sabem fazer a devida escolha e o conveniente emprego dos adubos, onde é indispensável que entrem certas matérias, como a potassa, a soda, a cal, a alumina, etc.

\footnotetext{
66 Idem ibidem. p. 125-126. O Governo paulista abriu concorrência para a exploração da apatita em Ipanema apenas na década de 1920.

${ }^{67}$ Alguns autores afirmam que a produção para consumo interno (gêneros alimentares) apenas conseguiu suprir a demanda do mercado nas décadas de 1920-30. Ver por exemplo: SALLUM JR, Brasílio. op. cit.

68 SÃO PAULO (Estado). op. cit., p. 79.

69 G, P. "A Cal e a Agricultura." Revista Agrícola, ano III, n. 24, 1897. p. 179-180. p. 127. Sobre o autor desse artigo: a sigla G.P. deve tratar-se de Bernardo Avelino Gavião Peixoto (1829-1912) que escrevia com recorrência na Revista Agrícola, e assinava seus artigos sob a sigla citada.
} 
Em razão do nome, há quem pense que a cal aquece o que está frio e que divide o que está muito apertado ou compacto. Isto não passa, todavia de um preconceito. ${ }^{70}$

Salientou aos leitores do periódico que a cal convinha de ser aplicada em todos os terrenos em cuja composição houvesse carência daquele produto, fossem eles terrenos de argila compacta ou de areia silicosa, o xisto ou o granito. A cal deveria "fazer parte do sustento dos cereais, das plantas industriais e dos legumes". Não funcionava, a seu ver, somente como elemento nutritivo, "mas também como substância para decompor e ainda como substância própria para impedir o efeito dos ácidos e destruir os insetos nocivos." 71

Desta maneira, quando a cal fosse destinada a terrenos com abundância de detritos vegetais naturais, e oriundos da queimada das florestas, ou colocados pelo próprio homem como restos de outras plantações, portanto, adubo natural, conviria empregar a cal "viva ou cáustica" quanto possível e na razão de 100 a 129 hectolitros $^{72}$ por hectare $^{73}$, e quando fosse destilada (ou dissolvida) serviria "somente a corrigir, a neutralizar a acidez de um terreno ou a enriquecê-los de elementos calcários, ou ainda quando se deseja misturá-la com os estercos, é melhor empregá-la extinta (neutra)." ${ }^{\prime 4}$ Este seria, a seu ver, o melhor modo de corrigir um terreno ácido utilizando a cal para adubação.

A despeito do uso da terra para a agricultura, o fazendeiro e industrial, Luiz de Queiroz, era enfático e crítico quanto à prática das queimadas das florestas para abertura de áreas. Para 0 autor, "destruir soberbas matas de terra ubérrimas, que vão ser entregues para sempre à cultura, não é grande mal e mesmo não se poderia recriminar contra esta prática se toda a madeira de lei fosse aproveitada." O autor era contra o uso indiscriminado da derrubada e queimada, do pouco aproveitamento do solo durante as décadas, e de suas madeiras, que poderiam ser utilizadas para diferentes fins, visto a exploração do solo praticada no Brasil, sem reposição alguma dos nutrientes, onde as plantações não eram feitas acompanhando o desnível dos terrenos (curvas de nível), o que um historiador denominou de "verdadeiro processo de bombeamento dos recursos naturais do solo, agricultura extrativa". ${ }^{75}$

Segundo observou Queiroz, na sua crítica sobre as práticas agrícolas encetadas historicamente:

\footnotetext{
70 G, P. op. cit., p. 179-180.

71 Idem ibidem. P. 180.

72 Medida de capacidade, equivalente a 100 litros.

73 Unidade de medida agrária, equivalente a cem ares. 0 are é também uma unidade de medida agrária e equivalente a 100 metros quadrados.

74 G.P. op. cit., p. 180.

75 PRADO JR, Caio. Formação do Brasil Contemporâneo. São Paulo: 23ª ed. Brasiliense, 1999. p. 136.
} 
[...] destruir matas e capoeiras só para tirar duas ou três colheitas, atear fogo em quase um distrito inteiro, para fazer verde (pasto) a algumas cabeças de gado, queimar imensos campos e matas pela locomotiva de estrada de ferro mal dirigida, ou arrasar florestas de íngremes morros, de profundas barrocas de nascentes d'água ou de beirario, ou inutilizar as matas junto a centros populosos só para aproveitá-las com carvão ou lenha, é simplesmente procedimento de bugres ou de vândalos e o governo ou mesmo as Câmaras Municipais deveriam com leis as mais severas pôr um paradeiro a tão insensato, quão imprudente procedimento. ${ }^{76}$

Advertia que devido às queimadas, e ao abandono do solo nu, com a destruição exagerada das florestas, o clima do país estava se modificando completamente: "as estações tornam-se irregulares, as chuvas ora vem cedo, ora tarde, ou são escassas ou são copiosas demais, os rios tornam-se caudalosos", devido à lavagem e carregamento da camada superficial dos terrenos e a lixiviação, "e há fortes inundações ou então secam quase completamente, a ponto de não darem água para fazer trabalhar a mais insignificante máquina"; os ventos estavam sempre emprenhados de "forte camada de pó, o calor, torna-se abrasador; tudo isso contribui para o mal estar dos habitantes e também para a irregularidade da produção, esterilizando o país pouco a pouco". ${ }^{77}$ № entanto, sabia o viajado industrial que:

[...] se hoje os países os mais adiantados da Europa tem obtido maior produção, não é só devido a sua sábia agronomia, mas a sensata conservação que eles têm sabido dar à suas florestas aumentando-as diariamente e apoiados por sabias leis que são fielmente cumpridas; isto tem também contribuído poderosamente para estabelecer um clima igual, havendo completa uniformidade das mudanças das estações, aumentando sempre sua produção, até não the faltando nem lenha, nem madeira que é obtida por preço inferior ao que pagamos nós, o que não deixa de muito contribuir para o seu bem estar. ${ }^{78}$

Portanto, os lavradores brasileiros deveriam cuidar melhor dos seus terrenos e lavouras, "tratar de não destruir tanto as nossas matas e fazer novas florestas em terras inúteis à lavoura e que para o futuro serão de grande interesse pecuniário e verdadeira e sólida herança a família". Lembrava como essências florestais de crescimento rápido e de excelente madeira, como o cedro, o pinheiro, o guarantã e muitas outras, e as estrangeiras como os eucaliptos, as coníferas, os carvalhos, poderiam fornecer em alguns anos, material para a construção civil em geral, entre dezenas de outros fins comerciais, desejando ver o desenvolvimento da silvicultura comercial em São Paulo.

Acrescentava que para a cultura dessas árvores "há despesas só nos primeiros 4 a 5 anos, porque depois a sua conservação poucos gastos ocasiona"; estava convencido que cada árvore

${ }^{76}$ QUEIROZ, Luiz Vicente de Souza. "Apelo ao Governo e às Câmaras Municipais - Destruição das Matas." Revista Agrícola, ano I, n. 7, 1895. p. 112. Referências: bugres: um indivíduo rude, inculto. Vândalos: ato de destruição de uma coisa útil, que deveria ser mais bem aproveitada neste sentido.

77 Idem ibidem. p. 112. A referência feita para "máquinas" seriam os aparelhos movidos à força hidráulica existentes em diversas propriedades.

78 Idem. p 112. 
poderia gerar uma renda de um a dois mil réis de madeira por ano. Somando-se a isso estava "a vantagem destas terras (onde fossem plantadas as árvores) muito aumentarem de valor, porque iriam pouco a pouco recuperando as suas forças produtivas." 79

\section{Considerações finais}

Diante do exposto, na leitura da Revista Agrícola, podemos visualizar o desejo de dezenas de homens, intelectuais, agrônomos, divulgadores entusiastas, políticos e grandes fazendeiros na busca da modernização, melhoramento da produção agrícola, conquanto se buscasse uma produção menos custosa, na economia de braços e maior rendimento das lavouras, algumas propostas de modernização e modificação da agricultura até então praticada no Brasil e em São Paulo neste artigo em específico.

Pode-se vislumbrar, diante das centenas de artigos contidos neste periódico, não apenas a feição comercial, econômica e utilitária daquelas propostas, mas também o surgimento de uma consciência particular e, como não, também pública dos recursos naturais e sua conservação ou ampliação (maximização) do seu uso econômico e social no tempo e espaço das propriedades e território pelo homem.

Na leitura da Revista Agrícola encontra-se a busca paulista (e também brasileira) da Moderna Agricultura que se desenvolveu durante o século XIX e no século XX adentro nos países europeus e nos Estados Unidos da América. Contudo, diante da leitura dos artigos contidos na revista analisada, pode ser visualizado que os intelectuais, fazendeiros e diversos personagens das ciências, da agricultura e da incipiente agronomia brasileira estavam atentos ao que de mais novo ou moderno os países ditos civilizados estavam realizando em matéria de agricultura. Neste sentido, aquelas pessoas - agrônomos, cientistas, fazendeiros e políticos -, tentaram de diversas maneiras trazer e implantar no Brasil - e não apenas transladar de outros países tidos como exemplo em matéria agronômica, como Estados Unidos da América e países europeus -, as técnicas agrícolas mais candentes na época, na tentativa de melhorar os métodos de cultivos do solos, a produção, onde o maior mote era: produzir muito e o mais barato possível.

\footnotetext{
79 QUEIROZ, Luiz Vicente de Souza. "Apelo ao Governo." op. cit., p 112.
} 


\section{Referências Bibliográficas}

\section{Fontes}

1. SÃO PAULO (Estado). Secretaria da Agricultura, Comércio e Obras Públicas. Relatório da Agricultura, apresentado ao Dr. Jorge Tibiriçá pelo Dr. Carlos Botelho, Secretário da Agricultura. 1904. São Paulo: Tipografia Brasil de Carlos Gerke. 1905.

2. Revista Agrícola. Órgão da Sociedade Pastoril e Agrícola. São Paulo, 1895.

3. REVISTA AGRÍCOLA. "Indústria Pastoril - A Indústria Pastoril em São Paulo - Seu Presente e seu Futuro - A Sociedade Pastoril e Agrícola - A 'Revista Agrícola.' N. 1 ano I, 1895. p. $1-5$.

4. CAPANEMA, Guilherme S. "As Queimadas." Revista Agrícola, ano I, n. 6, 1895. p. 91-93.

5. CONGRESSO AGRÍCOLA, [1878]. Coleção de Documentos. Rio de Janeiro: Fundação Casa de Ruí Barbosa, 1988.

6. G, P. "A Cal e a Agricultura." Revista Agrícola, ano III, n. 24, 1897. p. 179-180.

7. QUEIROZ, Luiz Vicente de Souza. "Fosfato de Cal." Revista Agrícola, ano I, n. 8, 1895, p. 126-127.

8. . "Apelo ao Governo e às Câmaras Municipais - Destruição das Matas." Revista Agrícola, ano I, n. 7, 1895. p. 112.

9. SOBRINHO, José Leite da Costa. "Caça e Pesca." Revista Agrícola, ano I, n. 2. 1895. p. 2122.

\section{Bibliografia}

1. ABRAMOVAY, Ricardo. Paradigmas do capitalismo agrário em questão. São Paulo: Edusp, 2007.

2. BOSERUP, Ester. Evolução Agrária e Pressão Demográfica. São Paulo: Hucitec e Polis, 1987.

3. CARDOSO, Ciro Flamarion Santana. Agricultura, escravidão e Capitalismo. Petrópolis: Vozes, 1979.

4. COSTA, Angela Marques da; SCHWARCZ, Lilia Moritz. 1890-1914: no tempo das certezas. São Paulo: Companhia das Letras, 2000.

5. DEAN, Warrean. Rio Claro: Um Sistema Brasileiro de Grande Lavoura 1820-1920. Rio de Janeiro: Paz e Terra, 1977.

6. A Ferro e Fogo: A História e a Devastação da Mata Atlântica Brasileira. São Paulo: Cia. das Letras, 1996. 
7. "The Green Wave of Coffee: Beginnings of Tropical Agricultural Research in Brazil." In: Hispanic American Historical Review. Duque University Press, Vol. 69, n. 1. 1989. P. 97-98.

8. DOBROWOLSKI, Kazimierz . "Peasant Traditional Culture." In: SHANIN, Theodor. (Org.) Peasants and Peasant Societies. Harmandsworth: Penguin books. 1979.

9. DOMINGUES, Heloisa M. Bertol. "As Ciências Naturais e a Construção da Nação Brasileira." Revista de História. N. 135, 2. sem. 1996, 41-60.

10. Ciência: um Caso de Política. As relações entre Ciências Naturais e a Agricultura no Brasil-Império. Tese (Doutorado em História). São Paulo: FFLCH-USP, 1995.

11. ELSTER, Jon. "La Motivación de los agentes económicos en el pasado." In: TOPOLSKI, J. História Econômica. Nuevos enfoques y nuevos problemas. Barcelona: Crítica. 1981.

12. FIGUEIRÔA, Silvia Fernanda de Mendonça. "Ciência e tecnologia no Brasil Imperial Guilherme Schuch, Barão de Capanema (1824-1908)." Varia História. V. 21, n 34, p. 437455, 2005.

13. FRAGOSO, João Luis Ribeiro. "A Roça e as Propostas de Modernização na Agricultura Fluminense do Século XIX: O Caso do Sistema Agrário Escravista - Exportador em Paraíba do Sul". Revista Brasileira de História. (ANPUH) Vol. 6, №12, Março-agosto, 1986, pp. 125126.

14. FREITAS FILHO, Almir Pita. "Tecnologia e escravidão no Brasil: aspectos da modernização agrícola nas Exposições Nacionais da segunda metade do século XIX (1861-1881)." Revista Brasileira de História, v.11 (22), mar-abr. 1991. p.71-92.

15. HENRIQUES, Amilson Barbosa. A Cultura Rotineira e a Lavoura Racional: proposições na Revista Agrícola (São Paulo, 1895-1907). Dissertação (Mestrado em História) FCL-UNESPAssis, 2010.

16. HOBSBAWM, Eric J. Era dos Extremos: o breve século XX: 1914-1991. São Paulo: Companhia das Letras, 1995.

17. A Era do Capital. Rio de Janeiro: Paz e Terra, 1975.

18. HOLANDA, Sérgio Buarque de. "Persistência da lavoura do tipo predatório." In: Raízes do Brasil. São Paulo: Companhia das Letras, 1995. p. 66-70.

19. LEMOS, Carlos. Alvenaria Burguesa. São Paulo: Nobel, 1989.

20. LINHARES, Maria Yedda L. "Subsistências e Sistemas Agrários na Colônia: Uma Discussão." São Paulo: Revista Estudos Econômicos, IPE, USP, Volume 13, 1983.

21. LOVE, Joseph L. A Locomotiva: São Paulo na federação brasileira 1889-1937. Trad. Vera Alice Cardoso Silva. Rio de Janeiro: Paz e Terra, 1982. 
22. MATOS, Odilon Nogueira de. Café e Ferrovias: A evolução ferroviária de São Paulo e o desenvolvimento da cultura cafeeira. $4^{\text {a }}$ ed. Campinas: Pontes, 1990.

23. MELONI, Reginaldo Alberto. Ciência e Produção Agrícola: A Imperial Estação Agronômica de Campinas 1887-1897. São Paulo: Humanitas, 2004.

24. MELLO E SOUZA, Antônio Candido de. Os Parceiros do Rio Bonito. Estudo sobre o caipira paulista e a transformação dos seus meios de vida. $3^{a}$ Ed. São Paulo: Livraria Duas Cidades, 1975.

25. MORAES, Carlos R. de. Meio Ambiente e Ciências Humanas. São Paulo: Annablume, 2005.

26. MUNARI, Lúcia Chamlian. Memória social e ecologia histórica: a agricultura de coivara das populações quilombolas do Vale do Ribeira e sua relação com a formação da Mata Atlântica. Dissertação (Mestrado em Ciências). Universidade de São Paulo. Instituto de Biociências, 2009.

27. PERECIN, Marly Therezinha Germano. Os Passos do Saber. a Escola Agrícola Prática Luiz de Queiroz. São Paulo: Editora da Universidade de São Paulo, 2007.

28. PRADO JR, Caio. Formação do Brasil Contemporâneo. São Paulo: $23^{a}$ ed. Brasiliense, 1999.

29. SALLES, Iraci Galvão. Trabalho, Progresso e a Sociedade Civilizada: o Partido Republicano Paulista e a Política de Mão-de-Obra (1870-1889). São Paulo: Hucitec, 1986.

30. SALLUM JR, Brasílio. Capitalismo e Cafeicultura: Oeste Paulista - 1888-1930. São Paulo: Duas Cidades, 1982.

31. SCHMIDT, Carlos Borges. Técnicas Agrícolas Tradicionais e Primitivas. São Paulo: Conselho Federal de Cultura e Departamento de Assuntos Culturais, 1976.

32. SEVCENKO, Nicolau. Literatura como Missão: tensões sociais e criação cultural na Primeira República. 2. ed. São Paulo: Companhia das Letras, 2003.

33. _. Orfeu Extático na Metrópole: São Paulo, sociedade e cultura nos frementes anos 20. São Paulo: Companhia das Letras, 1992.

34. . "O Front Brasileiro na Guerra Verde: vegetais, colonialismo e cultura." Revista USP. n. 30, 1996, p. 108-119.

35. SLICHER VAN BATH, Bernard. História Agrária da Europa Ocidental (500-1850). Lisboa: Presença, 1976.

36. STOLKE, Verena. Cafeicultura: Homens, Mulheres e Capital (1850-1980). São Paulo: Brasiliense, 1986.

37. TRIMBLE, Stanley. "Perspectives on the History of soil erosion control in the Eastern United States." In: Agricultural History Review. N. 59, 1985. 
38. WORSTER, Donald. "Transformações da Terra: para uma perspectiva agroecológica na história". Ambiente \& Sociedade, Campinas, v. V, n. 2, ago./dez. 2002; v. VI, n. 1, jan./jul. 2003.

39. ZARTH, Paulo Afonso. "Tecnologia e agricultura: das práticas rotineiras aos exemplos dos povos cultos." Primeiras Jornadas de História Regional Comparada. Porto Alegre, 2000.

Artigo recebido em: 05/09/2011

Aprovado para publicação em: 01/11/2011 